\title{
YAP and TAZ are required for the postnatal development and the maintenance of the structural integrity of the oviduct
}

\author{
Philippe Godin ${ }^{1,2}$, Mayra Tsoi ${ }^{1,2}$, Marilène Paquet ${ }^{2,3}$ and Derek Boerboom ${ }^{1,2}$ \\ ${ }^{1}$ Département de biomédecine vétérinaire, Faculté de médecine vétérinaire, Université de Montréal, St-Hyacinthe, \\ Canada, ${ }^{2}$ Centre de Recherche en Reproduction et Fertilité, Faculté de médecine vétérinaire, Université de \\ Montréal, St-Hyacinthe, Canada and ${ }^{3}$ Département de pathologie et de microbiologie, Faculté de médecine \\ vétérinaire, Université de Montréal, St-Hyacinthe, Canada
}

Corresponding should be addressed to D Boerboom; Email: derek.boerboom@umontreal.ca

\begin{abstract}
The development of the Müllerian ducts into the female reproductive tract requires the coordination of multiple signaling pathways that regulate proliferation, apoptosis and differentiation. The Hippo pathway has been reported to interact with several pathways with established roles in Müllerian duct development; yet, its potential roles in reproductive tract development and function remain mostly uncharacterized. The objective of this study was therefore to characterize the roles of the Hippo transcriptional coactivators YAP and TAZ in the female reproductive tract using transgenic mouse models. This report shows that the concomitant conditional inactivation of Yap and Taz in the mouse Müllerian duct mesenchyme results in postnatal developmental defects of the oviduct. Most notably, discontinuities in the myosalpinx layer lead to the progressive formation of cystic dilations of the isthmus. These defects prevented embryo transport and subsequent implantation in older animals, causing infertility. The loss of YAP/TAZ did not appear to affect other biological processes known to be required for the maintenance of oviductal wall integrity, such as TGF- $\beta$ /SMAD and Notch signaling and the biogenesis of miRNA, suggesting that the Hippo pathway acts independently of these processes to direct oviduct development. Taken together, these results suggest redundant and essential roles for YAP and TAZ in the postnatal development of the oviduct and the maintenance of its structural integrity.

Reproduction (2020) $\mathbf{1 6 0} 307-318$
\end{abstract}

\section{Introduction}

The Müllerian ducts (or paramesonephric ducts) are a pair of simple tubular structures present during embryogenesis that give rise to the oviducts, uterus and upper third of the vagina. Müllerian duct development is divided into three major steps: specification of Müllerian duct precursors at the cranial pole of the mesonephros, their invagination into the underlying mesenchyme with formation of the lumen, and the caudal elongation of the ducts until they fuse with the urogenital sinus (Roly et al. 2018). These steps require tightly synchronized signals, mediated by multiple signaling pathways and regulators, to direct cell proliferation, apoptosis, migration and differentiation. Key mediators of Müllerian duct development include Lim1, Pax2, Emx2 and Wnt4, the targeted deletion of which results in complete Müllerian agenesis in the mouse (Torres et al. 1995, Miyamoto et al. 1997, Vainio et al. 1999, Kobayashi et al. 2004).

Hippo is an evolutionarily conserved signaling pathway that is involved in a number of cellular processes including proliferation, apoptosis and differentiation. It is a crucial regulator of morphogenesis, organ size determination and tumorigenesis in many tissues including the heart (Zhou et al. 2015), liver (Patel et al. 2017), kidneys (Wong et al. 2016) and mammary gland (Shi et al. 2015). The Hippo pathway has no specific ligand, but can respond to a variety of stimuli, including cues from the cellular environment such as cellular density, extracellular matrix stiffness and shear stress (Meng et al. 2016). These activate a core kinase cascade that ultimately results in the phosphorylation of the transcriptional co-regulatory proteins Yes-associated protein (YAP) and transcriptional coactivator with PDZbinding motif (TAZ) (Zhao et al. 2007). Additional phosphorylation of YAP/TAZ by casein kinase 1 results in their ubiquitination by $\beta-\operatorname{TrCP}$ and subsequent proteasomal degradation (Liu et al. 2010, Zhao et al. 2010). Alternatively, phosphorylated YAP/TAZ can also bind proteins of the 14-3-3 family, resulting in their retention in the cytoplasm (Zhao et al. 2007). In the absence of Hippo signaling activity, unphosphorylated YAP/TAZ localize to the nucleus, where they bind various transcription factors (notably those of the TEAD family) to exert their transcriptional regulatory actions (Piccolo et al. 2014). YAP/TAZ transcriptional target 
genes include those of the $\mathrm{CCN}$ family of matricellular proteins (Cyr61, Ctgf, Nov), which are involved in diverse cellular processes such as proliferation, adhesion, extracellular matrix production, differentiation and apoptosis (Lau \& Lam 1999). Although their biological roles are distinct (as evidenced by the divergent phenotypes of their respective knockout mouse models (Morin-Kensicki et al. 2006, Hossain et al. 2007)), YAP and TAZ have been shown to act in a functionally redundant manner in several cellular contexts (Plouffe et al. 2018). In addition to their roles as transcriptional co-regulators, YAP/TAZ have also been shown to interact with components of other pathways such as Wnt, transforming growth factor beta (TGF $\beta$ ) and Notch (Hansen et al. 2015), thereby modulating their signaling activity. In addition, YAP has been reported to regulate miRNA processing by interacting with components of the miRNA biogenesis machinery (Chaulk et al. 2014, Mori et al. 2014).

Little information exists regarding the roles played by the Hippo pathway in the female reproductive tract. Strakova et al. (2010) reported that in vitro decidualization of human uterine fibroblasts is accompanied by a decrease in TAZ levels, which also occurs in the endometrium during the early stages of baboon pregnancy. Chen et al. (2017) reported that YAP expression is higher in human decidual cells from early pregnant decidua in comparison with the non-pregnant endometrium and that knockdown of YAP expression in cultured endometrial stromal cells interferes with decidualization in vitro. Together, these studies suggest that Hippo may play a role in decidualization and the establishment of pregnancy. The only study of Hippo function during reproductive tract development reported thus far examined the phenotype of mice with a conditional deletion of the Hippo kinases Lats 1 and Lats 2 in the mesenchyme cells of the Müllerian duct. Loss of Hippo signaling in targeted cells caused them to lose their multipotency and to commit to the myofibroblast cell fate, resulting in severe developmental defects of the uterus and oviducts (St-Jean et al. 2019). These changes were caused, at least in part, by markedly increased levels of YAP and TAZ protein levels, which directly drove increased transcriptional activity of Ctgf.

To further study roles of YAP and TAZ in female reproductive tract development and function, we generated mouse models to inactivate Yap and/or Taz in Müllerian mesenchyme cells. Loss of Hippo signaling in the double conditional knockout model resulted in developmental defects of the myosalpinx, causing the isthmi of the oviducts to become progressively dilated. This in turn caused oocytes and blastocysts to become entrapped, resulting in a progressive decrease in fertility. Our findings represent direct evidence of a role for YAP/TAZ in oviduct development, and further identify the Hippo pathway as an important regulator of female reproductive tract development.

\section{Materials and methods}

\section{Animal models}

Mice bearing floxed alleles for Yap and/or Taz (described in (Xin et al. 2011, 2013), referred to herein as Yap ${ }^{\mathrm{f} / \mathrm{f}}, \mathrm{Taz}^{\mathrm{f} / \mathrm{f}}$ and Yap/Taz ${ }^{\mathrm{f} / \mathrm{f}}$ ) were graciously provided by Eric Olson (University of Texas Southwestern Medical Center). Genotyping analyses were performed as previously described (Xin et al. 2011, 2013) on DNA extracted from tail biopsies, and using the following PCR conditions: $2 \mathrm{~min}$ at $94^{\circ} \mathrm{C}$ for one cycle, $30 \mathrm{~s}$ at $94^{\circ} \mathrm{C}, 30 \mathrm{~s}$ at $60^{\circ} \mathrm{C}$ and $40 \mathrm{~s}$ at $72^{\circ} \mathrm{C}$ for 35 cycles, and $4 \mathrm{~min}$ at $72^{\circ} \mathrm{C}$ for one cycle. These mice were mated to the $A m h r 2^{\text {tm3(cre)Bhr }}$ (referred to herein as Amhr2 ${ }^{\text {cre }}$ ) strain (provided by Richard R. Behringer (M.D. Anderson Cancer Center, Houston, TX, USA)) to generate single and double knockout mouse models. Genotyping analyses for Amhr2 $2^{\text {cre }}$ were conducted as previously described (Jorgez et al. 2004). Females of the Gt(ROSA)26Sor ${ }^{\text {tm9(CAG-tdTomato)Hze }}$ reporter strain (referred to herein as CAG-tdTomato) were acquired from Jackson Laboratory (Jackson Laboratory, stock number 007909). Genotyping analyses were performed according to the Jackson Laboratory protocol (protocol \#29436, available online at https://www.jax.org/Protocol?stockNumber $=00790$ 9\&protocolID=29436, accessed in March 2020) except that GoTaq Green Master Mix was used (Promega Corporation). All animal procedures were approved by the Comité d'éthique de l'utilisation des animaux (CÉUA) de la Faculté de médecine vétérinaire de I'Université de Montréal and conformed to the International Guiding Principles for Biomedical Research Involving Animals.

\section{Breeding trial}

Six-week-old single and double knockout female mice and control littermates ( $n=6 /$ genotype) were placed in cages with 6-week-old WT (C57BL/6J) males. Cages were monitored regularly to record intervals between litters and litter sizes. Males were replaced after 6 months, the replacement males were removed 2 months afterward and the experiment concluded 22 days later to allow the birth of a final litter.

\section{Tissue collection}

Ovaries, oviducts and uteri were dissected from 3 wk-, 2 mo-, 6 mo- and 10 mo-old $\mathrm{Yap} / \mathrm{Taz}^{\mathrm{f} / \mathrm{f}} ;$ Amhr $2^{\mathrm{cre} / \mathrm{+}}$ and control littermates and either (1) fixed in 10\% formalin and embedded in paraffin for histopathology analyses, immunohistochemistry or TUNEL analyses or (2) flash-frozen followed by homogenization for RT-qPCR analysis. Isthmus regions were collected by dissection following uncoiling of the oviducts and the identification of the ampulla-isthmus and uterotubal junctions. 5-Bromo-2'deoxyuridine (BrdU) (B5002 - MilliporeSigma) was reconstituted in sterile saline and administered (100 mg/kg, IP) $3 \mathrm{~h}$ prior to uteri collection to evaluate proliferation in decidual cells.

\section{Ovulation rate}

Five-month-old females ( $n=6$ /genotype) were mated with WT males and checked daily for the presence of a copulatory 
plug. On the morning of the identification of the plug, oviducts were isolated, placed in PBS, the cumulus-oocyte complexes (COCs) released from the ampullae by tearing the oviducts with forceps, and the COCs counted under a dissection microscope.

\section{Artificial induction of decidualization}

Protocol was based on that of Deb et al. (2006). Briefly, 3-month-old females were mated with vasectomized WT males and checked daily for copulatory plugs. Three days following the identification of the plug, decidualization was induced artificially by surgical injection of $20 \mu \mathrm{L}$ of sesame oil in the lumen of the left uterine horn. The contralateral horn was not injected and acted as a control. Females were euthanized 7.5 $\mathrm{dpc}$, and their uterine horns were weighed and fixed in $10 \%$ formalin for further analyses.

\section{Oviductal flush}

Oviducts from 5-month-old females ( $n=6 /$ genotype) were collected at $6.5 \mathrm{dpc}$ and placed in PBS. A 30G needle was inserted through the infundibulum and the oviductal lumen was flushed with PBS to retrieve unfertilized oocytes and embryos as previously described (Deb et al. 2006). These were fixed at room temperature in $4 \%$ paraformaldehyde for 40 mins, washed 6 times in PBS with 1\% Triton X-100 (Bioshop, Burlington, ON, Canada,) and mounted in a drop of Vectashield mounting medium with DAPI (Vector Laboratories, Burlingame, CA, USA). They were then counted and analyzed by fluorescence microscopy using a Leica DMIRB contrast microscope (Leica Microsystems).

\section{Steroid hormone measurements}

Serum progesterone (P4) levels of 2-month-old pregnant mice were measured by ELISA (IBL America). Assays were done by the Ligand Assay and Analysis Core, University of Virginia, VA, USA.

\section{Immunohistochemistry and tunel assays}

Immunohistochemistry analyses were performed using $3 \mu \mathrm{m}$ sections. Sections probed with primary antibodies against YAP, TAZ, PCNA, Cleaved Caspase-3 (14074, 4883, 2586 and 9661, respectively - Cell Signaling Technology), BrdU (M0744 - Agilent Technologies), Ki-67 (NB500-170 Novus Biologicals, Centennial, CO, USA), SMAD2 (ab47083 - Abcam), p-SMAD3 (LS-B64 - Lifespan Biosciences, Seattle, WA, USA) and DICER1 and DDX17 (sc-136979 and sc-398168, respectively - Santa Cruz Biotechnology) were treated with the Vectastain Elite ABC HRP Kit (Vector Laboratories) according to the manufacturer's instructions, followed by staining using the DAB Peroxidase (HRP) Substrate kit (Vector Laboratories). Sections probed with antialpha smooth muscle actin ( $\alpha$-SMA) antibody (MU128-UC BioGenex, Fremont, CA, USA) were treated with Dako REAL EnVision Detection System (K5007 - Agilent Technologies) using a Lab vision autostainer 360 (Thermo-Fisher Scientific) according to the manufacturer's instructions. All sections were counterstained with hematoxylin before mounting. Terminal deoxynucleotidyl transferase (TdT) dUTP Nick-End Labeling (TUNEL) assay was conducted with the In Situ Cell Death Detection Kit, TMR red according to the manufacturer's instructions (12156792910 - Roche Diagnostics). Slides were permeabilized in a $0.1 \%$ sodium citrate solution containing $0.1 \%$ Triton X-100 and mounted in Vectashield mounting medium with DAPI.

\section{RT-qPCR and microRNA analyses}

Total RNA and microRNA were extracted using the RNeasy Mini and miRNeasy Micro isolation kits (Qiagen), respectively, and according to the manufacturer's instructions. RNA quantity and quality were assessed using a NanoDrop 1000 spectrophotometer (Thermo-Fisher Scientific). Total RNA was reverse-transcribed using the SuperScript Vilo cDNA Synthesis Kit (11754050 - Invitrogen) and qPCR reactions consisted of $2.3 \mu \mathrm{L}$ of $\mathrm{H}_{2} \mathrm{O}, 6 \mathrm{pmol}$ of each forward and reverse genespecific primer and $7.5 \mu \mathrm{L}$ of Advanced qPCR mastermix with Supergreen (800-435-QL - Wisent, Saint-Jean-Baptiste, QC, Canada). Real-time PCR reactions were run using a CFX96 Real-Time System/C1000 Touch thermal cycler (Bio-Rad). The thermal cycling program consisted of: $3 \mathrm{~min}$ at $95^{\circ} \mathrm{C}$, followed by 40 cycles of $15 \mathrm{~s}$ at $95^{\circ} \mathrm{C}, 30 \mathrm{~s}$ at $60^{\circ} \mathrm{C}$ and $30 \mathrm{~s}$ at $72^{\circ} \mathrm{C}$. mRNA levels were determined using Bio-Rad CFX Manager Software (Bio-Rad), with the mathematical model according to Pfaffl (Pfaffl 2001) and using Rp/19 as the housekeeping gene. Primer sequences are listed in Table S1. RT-PCR and Real-time PCR for miR-143 were performed using a Taqman MicroRNA Assay (\#A25576 - Thermo Fischer Scientific) as directed by the manufacturer. snoRNA202 was used for normalization of miRNA levels.

\section{Statistical analysis}

Data of the fertility trial were analyzed by a two-way ANOVA followed by a Bonferroni post hoc test for multiple comparisons. RT-qPCR data are presented as mean \pm S.E.M. and were analyzed by Student's $t$-test. $P<0.05$ was considered statistically significant. Analyses were carried using GraphPad Prism software version 6.01 (GraphPad Software).

\section{Results \\ YAP and TAZ are expressed in the Müllerian ducts during embryogenesis}

To characterize YAP and TAZ expression in the developing Müllerian ducts, immunohistochemistry analyses were conducted on ducts isolated from WT mice at embryonic day 17.5. Results showed that both proteins were expressed in all Müllerian duct cell types, with localization mainly in the cytoplasm of ductal epithelial cells, and mostly in the nucleus of mesenchyme and coelomic epithelial cells (Fig. 1A). 


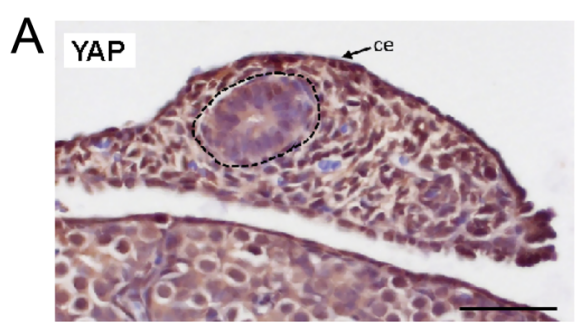

B
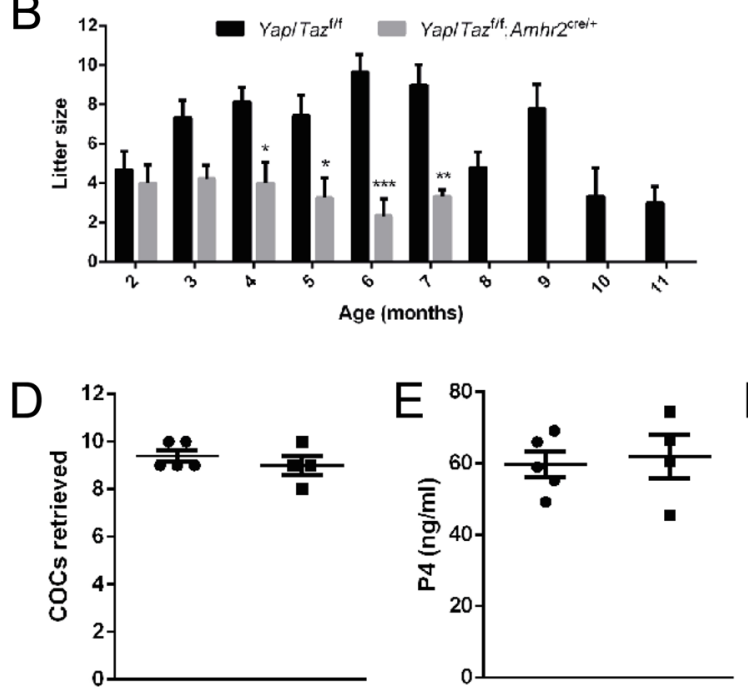
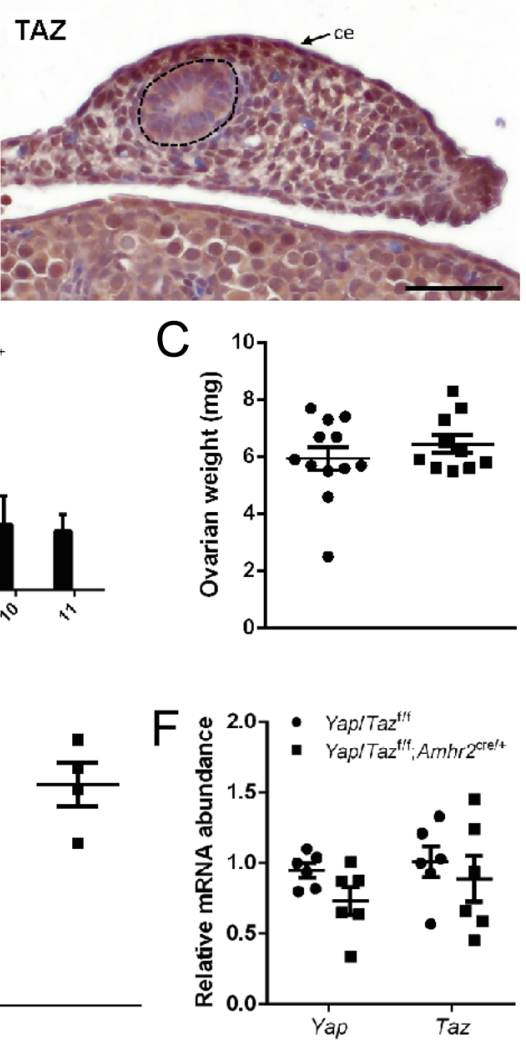

Figure 1 Müllerian ducts express YAP and TAZ and fertility of Yap/Taz ${ }^{\mathrm{f} / \mathrm{s}} ; A m h r 2^{\text {cre/+ }}$ females decreases with age in an ovary-independent manner. (A) Immunohistochemistry analyses of YAP and TAZ in Müllerian ducts of E17.5 WT female mice. Dashed lines separate the Müllerian duct epithelium and mesenchyme. $\mathrm{ce}=$ coelomic epithelium. Scale bars are 50 $\mu \mathrm{m}$. (B) Fertility of Yap/Taz ${ }^{\mathrm{fff}}$ and $\mathrm{Yap} / \mathrm{Taz}$; Amhr2 ${ }^{\text {cre/t+ }}$ females throughout a 10-month long trial. Data were analyzed by two-way ANOVA followed by Bonferroni post hoc test. ${ }^{*} P<0.05 ;{ }^{* *} P<0.01 ;{ }^{* * *} P<0.001$. (C) Ovarian weights of 10-month-old mice $(n=6$ females/genotype). (D) Ovulation rate of 5-month-old Yap/Taz ${ }^{\mathrm{f} / \mathrm{f}}$ and Yap/Taz $\mathrm{z}^{\mathrm{f} / \mathrm{f}}$; Amhr $2^{\text {cre/ }+}$ mice ( $n=5$ and 4). (E) Serum progesterone levels in $7.5 \mathrm{dpc}$ pregnant 2-month-old control and experimental females ( $n=5$ and 4). (F) RT-qPCR analyses of Yap and Taz mRNA levels in granulosa cells of 3-week-old Yap/Taz $z^{\mathrm{f} / \mathrm{f}}$ and Yap/Taz ${ }^{\mathrm{f} / \mathrm{f}} ;$ Amhr $2^{\text {cre/+ }}$ mice. Data are means \pm S.E.M.

\section{Yap/Taz ${ }^{\mathrm{f} / f} ; \mathrm{Amhr}{ }^{\text {cre/t }}$ female mice are subfertile}

To study the function of YAP and TAZ in female reproductive tract development and function, mice bearing floxed alleles for Yap and/or Taz were mated to mice of the $A m h r 2^{\text {cre }}$ strain. Yap/Taz ${ }^{\mathrm{ff}} ; A m h r 2^{\text {cre/+ }}$ mice were born at the expected Mendelian ratio. To assess fertility, Yap/Taz ${ }^{\mathrm{f} / \mathrm{f}} ; A m h r 2^{\text {cre/t }}$ females were mated with WT males for 8 months. Mutant females produced on average fewer pups per litter $(\mathrm{P}<0.001)$ (Table 1). Although the fertility of Yap/Taz ${ }^{\mathrm{f} / \mathrm{P}} ;$ Amhr2 $2^{\text {cre/ }}$ females was comparable to controls at the first litter, it declined progressively during the trial $(P<0.01)$, and no mutant mice produced pups past 7 months of age, whereas the majority of the controls (5/6) did (Fig. 1B). $\mathrm{Yap}^{\mathrm{fff}} ; \mathrm{Amhr}^{\mathrm{cre} /+}$ and $\mathrm{Taz} \mathrm{z}^{\mathrm{f} / \mathrm{f}} ; A m h r 2^{\text {cre/++ }}$ single conditional knockout models were as fertile as their respective controls and no phenotypic abnormalities were apparent (not shown), indicating that Yap and Taz are functionally redundant in this context.

Table 1 Fertility of Yap/Taz ${ }^{\mathrm{f} / \mathrm{f}}$ and $\mathrm{Yap} / \mathrm{Taz}{ }^{\mathrm{f} / \mathrm{f}} ; \mathrm{Amhr}^{\mathrm{cre} / \mathrm{+}}$ female mice.

\begin{tabular}{|c|c|c|}
\hline & Yap/Taz & Yap/Taz ${ }^{\mathrm{f} / \mathrm{f}} ; A m h r 2^{\text {cre/t }}$ \\
\hline Number of females & 6 & 7 \\
\hline Number of litters & 58 & 26 \\
\hline $\begin{array}{l}\text { Total number of } \\
\text { pups }\end{array}$ & 402 & 110 \\
\hline Litter size & $6.9 \pm 0.4$ & $4.2 \pm 0.4^{\mathrm{a}}$ \\
\hline Litter/month & $1.1 \pm 0.1$ & $0.4 \pm 0.1^{\mathrm{a}}$ \\
\hline
\end{tabular}

a $P<0.001$.

\section{Normal ovarian and uterine function in $\mathrm{Yap} / \mathrm{Taz}^{\mathrm{f} / f}$; Amhr2 ${ }^{\text {cre/t }}$ mice}

To investigate the cause of subfertility in the Yap/Taz f/f; Amhr $2^{\text {cre/t }}$ model, we examined the morphology and function of the principal tissues targeted by the Amhr2 $2^{\text {cre }}$ allele (i.e., reproductive tract structures derived from the Müllerian mesenchyme and ovarian follicular granulosa cells (Jamin et al. 2002)). Ovarian weights were similar between experimental and control females (Fig. 1C). Histological analyses revealed that all follicular stages and corpora lutea were present in the ovaries of adult $\mathrm{Yap} / \mathrm{Taz}^{\mathrm{ft} / \mathrm{f}} ; \mathrm{Amhr} 2^{\mathrm{cre} /+}$ mice, and no morphological abnormalities were detected (not shown). Ovulation efficiency following natural mating was assessed in 5 month-old mice, age at which fertility is reduced in Yap/Taz ${ }^{\mathrm{ff}} ;$ Amhr2 ${ }^{\mathrm{cre} / \mathrm{t}}$ females (Fig. 1B). The number of COCs retrieved from the oviduct ampullae of $\mathrm{Yap} / \mathrm{Taz} \mathrm{z}^{\mathrm{f} / \mathrm{f}}$; $A m h r 2^{\text {cre/t }}$ mice was not significantly different from the controls (Fig. 1D). Analyses of serum progesterone levels in pregnant females at $7.5 \mathrm{dpc}$ showed comparable levels between experimental and control females (Fig. $1 \mathrm{E})$, suggesting that smaller litter sizes were not due to luteal insufficiency. Analyses of Yap and Taz mRNA levels in adult Yap/Taz ${ }^{\mathrm{ff} / \mathrm{f}}$; Amhr2 $2^{\text {cre/+ }}$ ovaries were similar to controls (Fig. 1F), and immunohistochemistry analyses of YAP and TAZ expression also showed no differences between groups (Suppl Fig. 1A, see section on supplementary materials given at the end of this article). Together, these findings indicate that knockdown of Yap 
and Taz expression was inefficient in the ovary of the Yap/Taz ${ }^{\mathrm{f} / \mathrm{f}} ; A m h r 2^{\mathrm{cre} /+}$ model, and that ovarian function was unaffected.

As for the ovary, no obvious histological changes were observed in the uterus of $\mathrm{Yap} / \mathrm{Taz}^{\mathrm{f} / \mathrm{f}} ; A \mathrm{mhr} 2^{\mathrm{cre} /+}$ mice (not shown). As the Amhr $2^{\text {cre }}$ allele drives Cre expression in the stromal and decidual cells, decidualization was assessed by injection of oil in the lumen of the left uterine horn of pseudopregnant females (Fig. 2A). This resulted in similar uterine weight increases in $\mathrm{Yap} / \mathrm{Taz}^{\mathrm{f} / \mathrm{f}}$; Amhr $2^{\text {cre/+ }}$ relative to controls $(4.5 \pm 1.4$ fold increase in comparison to contralateral horn vs $4.9 \pm 2.2$ fold). Deciduomas were histologically indistinguishable between groups (Fig. 2B). Furthermore, decidual tissue was examined in pregnant females $7.5 \mathrm{dpc}$. This was also histologically indistinguishable between mutant and control mice, and BrdU incorporation analyses showed similar levels of proliferation of decidual cells in both groups (Fig. 2C). The myometrium (also targeted by the Amhr $2^{\text {cre }}$ allele) was similarly unaffected in mutant mice (not shown). Likewise, no evidence of increased embryo mortality or resorption was found in pregnant Yap/Taz ${ }^{\mathrm{f} / \mathrm{f}}$; Amhr $2^{\text {cre/+ }}$ mice (not shown). Evaluation of uterine Yap and Taz expression showed unchanged mRNA levels in 2-month-old Yap/Taz ${ }^{\mathrm{f} / \mathrm{f}} ; A m h r 2^{\mathrm{cre} /+}$ mice (Fig. 2D), and immunohistochemistry analyses also indicated similar expression levels between experimental and control females (Suppl Fig. 1B). These results therefore suggest that, as in the ovary, knockdown of Yap and Taz expression was inefficient in the uterus of the $\mathrm{Yap} / \mathrm{Taz}{ }^{\mathrm{f} / \mathrm{f}}$; Amhr $2^{\text {cre/+ }}$ model, and that decreased litter sizes were not due to inadequate uterine function.

\section{Oviduct defects in Yap/Taz ${ }^{\mathrm{f} / \mathrm{f}}$; Amhr2 ${ }^{\text {cre/+ }}$ mice}

Gross examination of the reproductive tracts of 10-month-old Yap/Taz ${ }^{\mathrm{f} / \mathrm{f}} ;$ Amhr2 ${ }^{\mathrm{cre} /+}$ females at the end of the fertility trial revealed marked bilateral cystic dilation of their oviducts (Fig. 3A). These dilations were often multilobulated, lined by thin, translucent walls and were located exclusively the isthmic region. In some cases, they were comparable in size to the ovary, and most appeared to contain cellular debris that was visible through the oviduct wall. To study the development of these cystic dilations, we also evaluated the macroscopic appearance of the oviducts of 3 wk-, 2 mo- and 6 mo-old mice. Oviducts from 3-week-old mice were indistinguishable from the controls. Half (3/6) of the 2-month-old mice had small dilations (less than the width of the oviduct) which did not contain debris. The other half had no dilations, but the external appearance of their oviducts was nonetheless distinguishable from the controls due to the presence of irregular bends and kinks (not shown). Oviducts from 6-month-old animals were very similar to those observed at 10 months of age (Fig. 3A). Histological analyses showed the oviductal cystic dilations of 10-month-old mutant animals to consist of a thin wall lined by an attenuated cuboidal epithelium surrounded by a thin stroma and outer serosa (Fig. 3B). $\alpha$-smooth muscle actin immunohistochemistry showed the isthmus myosalpinx of 3-week-old Yap/Taz ${ }^{\mathrm{f} / \mathrm{f}}$; Amhr $2^{\text {cre/t+ }}$ animals to be similar to controls. However, at 2 months of age, it was noticeably thinner and discontinuous in some areas. In 10-month-old animals the myosalpinx was thin, discontinuous, and completely absent in the most dilated areas (Fig. 3C). The oviduct dilations appeared to originate from the localized defects in the myosalpinx, suggesting they represented

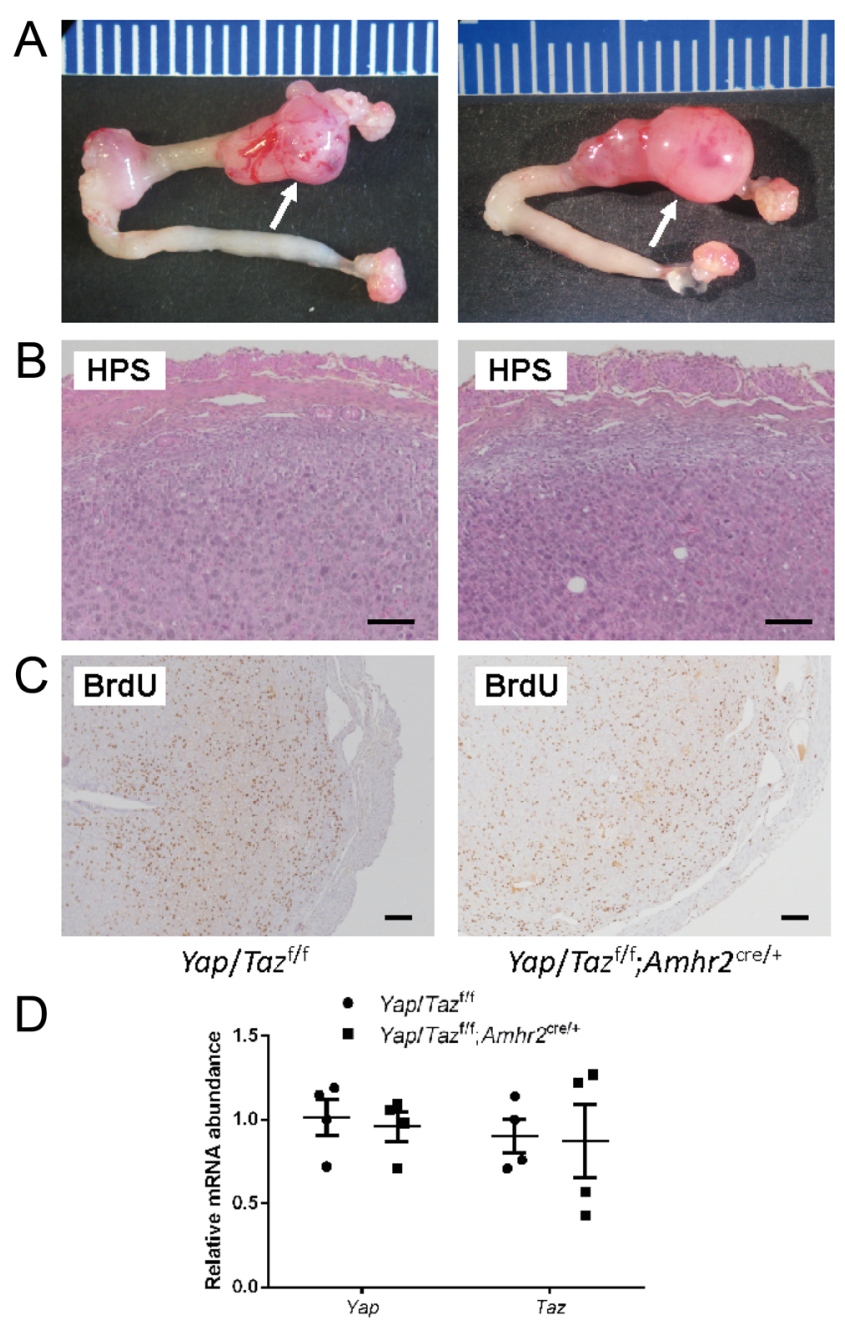

Figure $2 \mathrm{Yap} / \mathrm{Taz}$ f/f; Amhr2 $2^{\mathrm{cre} /+}$ uterus is unaffected. (A) Photomicrographs of artificially decidualized uteri of 3-month-old $\mathrm{Yap} / \mathrm{Taz}{ }^{\mathrm{f} / \mathrm{f}}$ and $\mathrm{Yap} / \mathrm{Taz}{ }^{\mathrm{f} / \mathrm{f}} ;$ Amhr $2^{\mathrm{cre} /+}$ mice. Arrows indicate decidualized regions of the injected horns. Representative images of staining with hematoxylin phloxine saffron (HPS) (B) and BrdU incorporation assays (C) of uteri of pregnant 3-month-old females at 7.5 dpc. (D) RT-qPCR analyses of Yap and Taz mRNA levels in whole uterine lysates of 2-month-old Yap/Taz ${ }^{\mathrm{f} / \mathrm{f}}$ and $\mathrm{Yap} / \mathrm{Taz}{ }^{\mathrm{f} / \mathrm{f}} ; A m h r 2^{\mathrm{cre} /+}$ mice. Ruler graduations are in millimeters. Scale bars are $100 \mu \mathrm{m}$. Data are means \pm S.E.M., $n=4$ animals/genotype. 

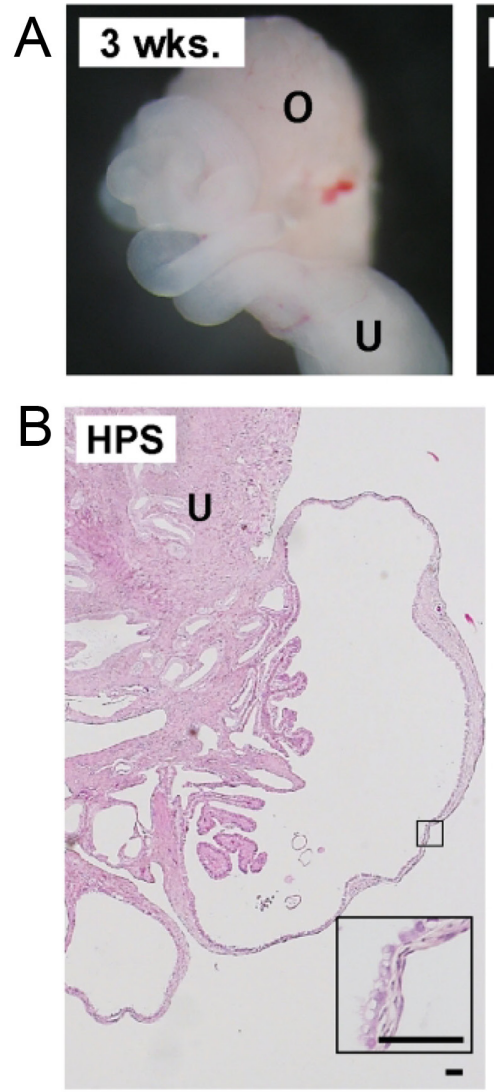
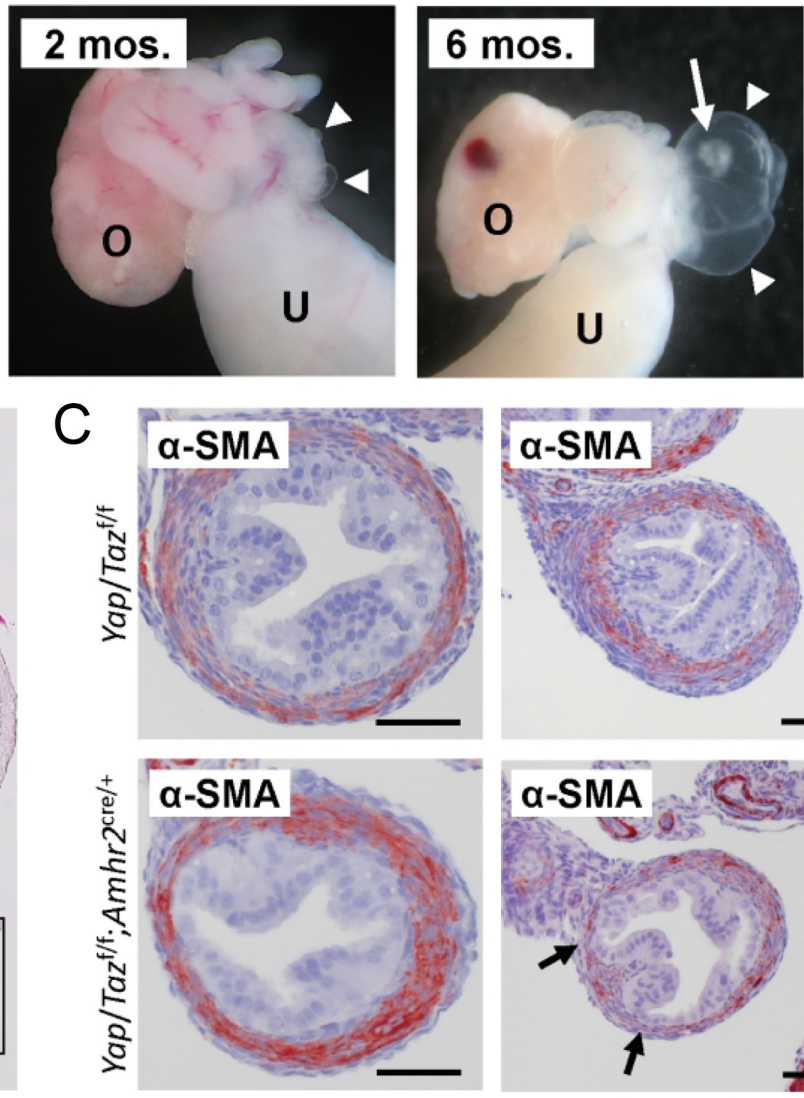

3 weeks
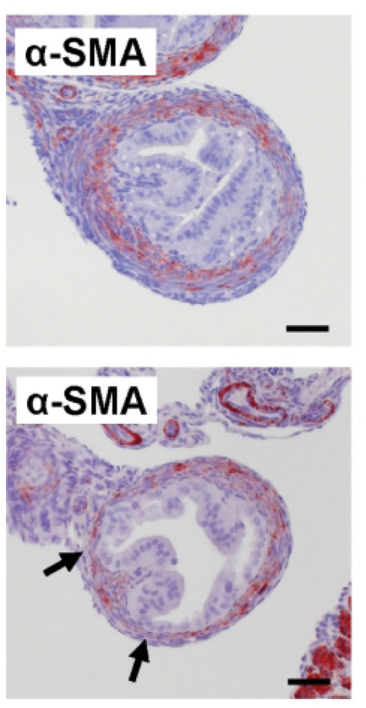

2 months
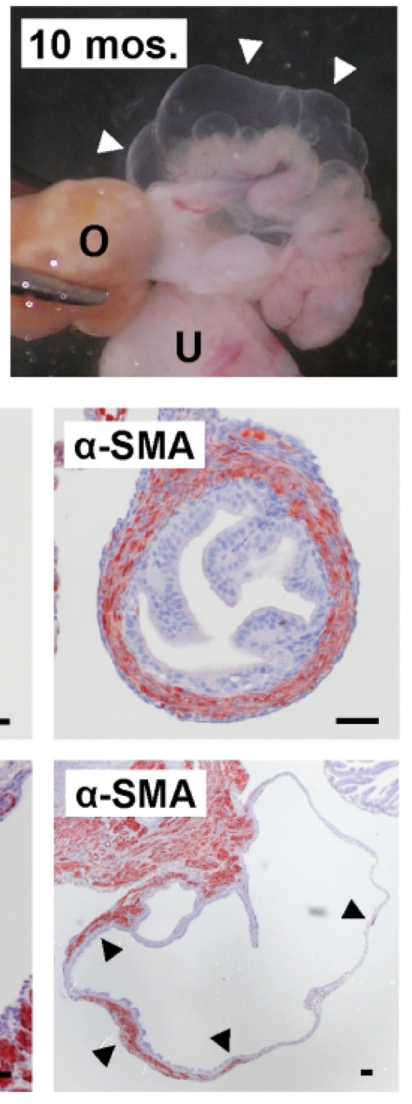

10 months

Figure $3 \mathrm{Yap} / \mathrm{Taz}$ f/f; Amhr2 ${ }^{\text {cre/t }}$ mice develop oviductal dilations concomitant with myosalpinx thinning. (A) Representative photomicrographs displaying the evolution of the oviductal phenotype with increasing age in $\mathrm{Yap} / \mathrm{Taz}^{\mathrm{f} / \mathrm{f}} ; \mathrm{Amhr} 2^{\mathrm{cre} / \mathrm{t}}$ mice. Arrowheads indicate dilations of the isthmus wall. Cellular debris are indicated by an arrow. (B) Oviductal dilation in a 10-month-old Yap/Taz ${ }^{\mathrm{f} / f}$; Amhr2 ${ }^{\text {cre/+ }}$ female. Inset shows the thin oviductal wall characterized by a cuboidal epithelium on a thin stroma. Stain = hematoxylin phloxine saffron (HPS). (C) $\alpha$-SMA immunohistochemistry analyses of 3-week-, 2- and 10-month-old isthmus sections. Arrows indicate discontinuities in the myosalpinx of a 2-month-old Yap/Taz ${ }^{f / f} ; A m h r 2^{\text {cre/+ }}$ mouse. Myosalpinx remnants in a 10-month-old Yap/Taz ${ }^{\mathrm{fff}} ; A m h r 2^{\text {cre/+ }}$ mouse are indicated by arrowheads. $\mathrm{O}$, ovary; U, uterine horn. Scale bars are $50 \mu \mathrm{m}$.

structural weak points at which oviductal intra-luminal pressure caused the dilations to arise (Fig. 3C).

The Amhr2 ${ }^{\text {cre }}$ strain is predicted to drive Cre activity in all tissues and cell types derived from the Müllerian duct mesenchyme, and phenotypic changes in the oviduct have been previously reported in conditional knockout mice using this strain (Hong et al. 2008, Nagaraja et al. 2008, Gonzalez \& Behringer 2009, Li et al. 2011, Ferguson et al. 2016, Rodriguez et al. 2016). However, a formal analysis of Cre activity in the oviduct of the $A m h r 2^{\text {cre }}$ model has not been previously reported. We therefore mated Amhr2 ${ }^{\text {cre }}$ mice with the CAG-tdTomato reporter strain to drive tdTomato expression in all cells expressing Cre. The resulting mice showed strong fluorescent signals in the myosalpinx and stromal cells of the isthmus (Fig. 4A), indicating that the Amhr2 $2^{\text {cre }}$ allele targets the latter tissues. Immunohistochemistry analysis of YAP and TAZ expression in the oviducts of Yap/Taz ${ }^{\mathrm{ff} / \mathrm{f}}$ Amhr2 ${ }^{\mathrm{cre} /+}$ mice showed a marked decrease for both proteins in the isthmus stroma and myosalpinx as early as 3 weeks of age (Fig. 4B). Yap and Taz mRNA levels was also found to be decreased in isolated isthmi from 3-week-old Yap/Taz ${ }^{\mathrm{fff}} ;$ Amhr2 ${ }^{\text {cre/ } / \mathrm{t}}$ females (Fig. 4C).

To characterize the cellular changes in the oviducts of $\mathrm{Yap} / \mathrm{Taz} \mathrm{z}^{\mathrm{f} / \mathrm{f}} ; \mathrm{Amhr} \mathrm{2}^{\mathrm{cre} / \mathrm{+}}$ mice that could give rise to the observed phenotype, we analyzed proliferation and apoptosis by Ki-67 immunohistochemistry and TUNEL, respectively. These assays failed to detect altered proliferation or apoptosis of the oviduct stromal or smooth muscle cells in Yap/Taz ${ }^{\mathrm{f} / \mathrm{f}} ; A m h r 2^{\text {cre/+ }}$ mice at any age examined (Fig. 4D and E and not shown). PCNA and Cleaved Caspase-3 immunohistochemistry yielded results similar to $\mathrm{Ki}-67$ and TUNEL, respectively (not shown).

\section{Oviductal dilations in the Yap/Taz ${ }^{\mathrm{f} / \mathrm{f}} ; \mathrm{Amhr} 2^{\text {cre/+ }}$ model trap oocytes and embryos}

Further investigation of the cellular debris present in the oviduct dilations of $\mathrm{Yap} / \mathrm{Taz}^{\mathrm{f} / \mathrm{f}} ; A \mathrm{mhr} 2^{\text {cre/+}}$ mice 

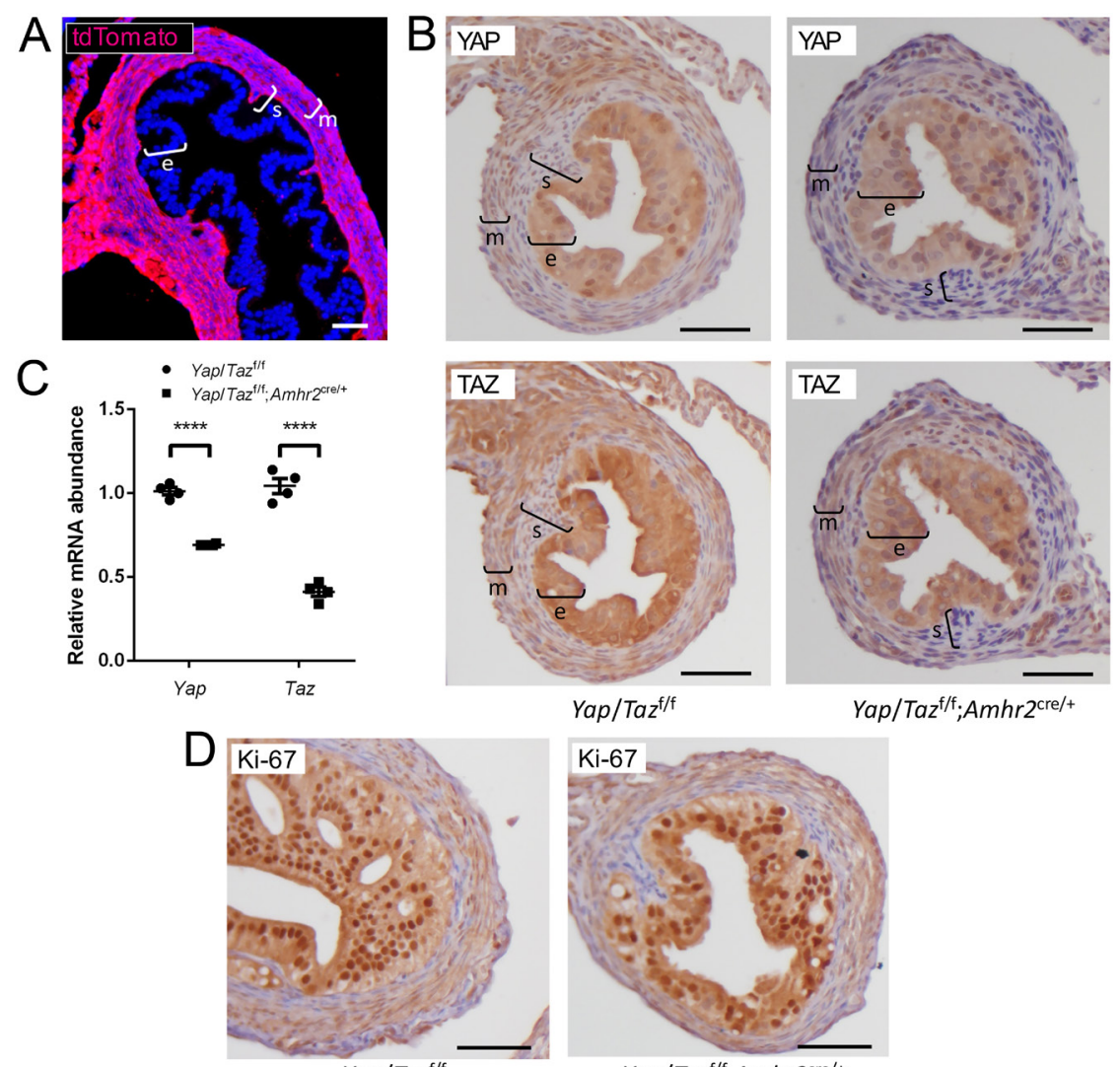

$\mathrm{Yap} / \mathrm{Taz}^{\mathrm{f} / \mathrm{f}}$

$\mathrm{Yap} / \mathrm{Taz}^{\mathrm{f} / \mathrm{f}}$
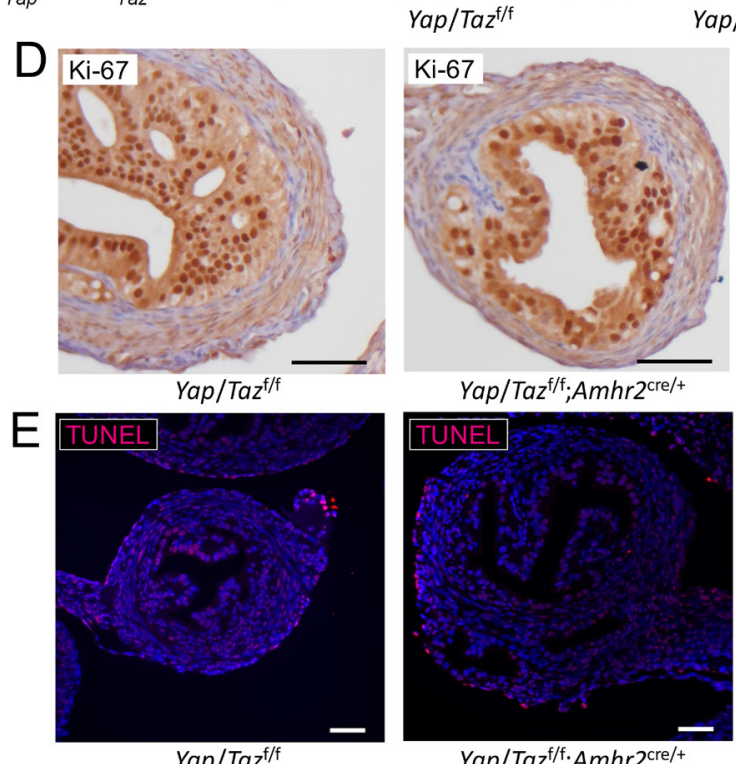

Yap/Taz ${ }^{\mathrm{f} / \mathrm{f}} ; A m h r 2^{\mathrm{cre} /+}$

$\mathrm{Yap} / \operatorname{Taz}^{\mathrm{f} / \mathrm{f}} ; A m h \mathbf{2}^{\mathrm{cre} /+}$
Figure 4 Loss of YAP and TAZ in the stroma and myosalpinx of Yap/Taz ${ }^{\mathrm{fff}} ; A m h r 2^{\text {cre/+ }}$ mice does not affect proliferation or apoptosis. (A) Fluorescence image showing the expression of td Tomato in the stroma and myosalpinx of the isthmus of a CAG-tdTomato;Amhr $2^{\text {cre/+ }}$ mouse. Immunohistochemistry (B) and RT-qPCR (C) analyses of Yap and Taz expression in the isthmus of 3-week-old Yap/Taz ${ }^{\mathrm{f} / \mathrm{f}}$ and $\mathrm{Yap} / \mathrm{Taz}^{\mathrm{f} / \mathrm{f}}$; Amhr2 ${ }^{\text {cre/+ }}$ mice. Immunohistochemistry analyses of Ki-67 (D) and fluorescence images of TUNEL assay (E) of isthmus sections of 2-month-old animals of the indicated genotypes. Scale bars are $50 \mu \mathrm{m}$. Data are means \pm S.E.M. analyzed by Student's $t$-tests, $n=4 .{ }^{* * * *} P<0.0001$ revealed spherical structures resembling oocytes (Fig. 5A). An apparent blastocyst was also observed in an oviductal dilation in a female at $7.5 \mathrm{dpc}$ (Fig. 5B), strongly suggesting that the dilations might entrap oocytes and embryos. To test this, we mated 5-monthold Yap/Taz ${ }^{\mathrm{f} / \mathrm{F}} ;$ Amhr2 $2^{\mathrm{cre} /+}$ and control females with WT males. As implantation normally occurs at $4 \mathrm{dpc}$ (Wang \& Dey 2006), females were killed $6.5 \mathrm{dpc}$. The uterus of $\mathrm{Yap} / \mathrm{TaZ} \mathrm{F}^{\mathrm{ff}} ; \mathrm{Amhr} 2^{\mathrm{cre} / \mathrm{t}}$ contained fewer implantation sites on average than controls $(0.4 \pm 0.4$ vs $6.8 \pm 1.7$ respectively) $(P<0.0001)$. Indeed, only one of seven Yap/Taz ${ }^{\mathrm{fff}} ; A m h r 2^{\text {cre/t }}$ mice had implantation sites, whereas the majority of the controls (4/5) did. Multiple structures consisting of individual cells or clusters of cellular material were visible through the thinned walls of the dilated isthmi in Yap/Taz $z^{\mathrm{ff}}$; Amhr2 ${ }^{\mathrm{cre} /+}$ mice (Fig. 5C). The oviducts from both groups were flushed, yielding 12 such structures on average per mouse from Yap/Taz ff; $A m h r 2^{\text {cre/t }}$ oviducts, whereas none were retrieved in controls. Following DAPI and fluorescence microscopy analysis, these were found to consist mainly of empty zona pellucidae, degenerated oocytes and embryos, with some unhatched late blastocysts (Fig. 5D). Taken together, these findings suggest that the progressive loss of fertility in Yap/Taz $z^{\mathrm{f} / \mathrm{f}}$; Amhr2 $2^{\mathrm{cre} / \mathrm{t}}$ females was due to the development of oviductal cystic dilations that resulted in oocyte and embryo entrapment.

\section{Loss of YAP/TAZ does not result in the dysregulation of biological processes known to affect oviductal wall integrity}

The oviductal dilations and myosalpinx abnormalities observed in Yap/Taz ${ }^{\mathrm{ff}} ;$ Amhr2 ${ }^{\mathrm{cre} /+}$ females are strikingly similar to what has been reported in mouse models harboring conditional deletions of Tgfbr 1 (Li et al. 2011), Smad1/5/4 (Rodriguez et al. 2016) and Dicer1 (Hong et al. 2008, Nagaraja et al. 2008, 
A

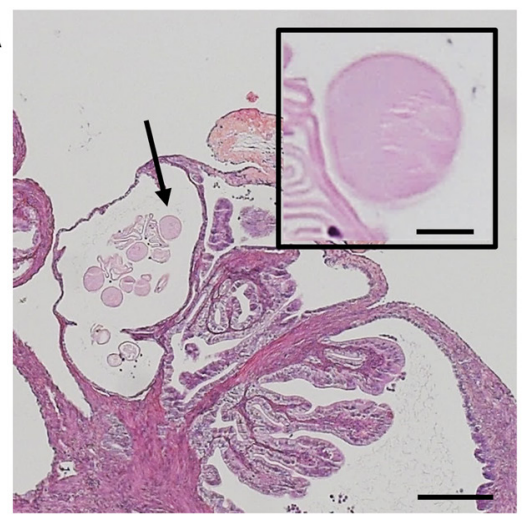

B

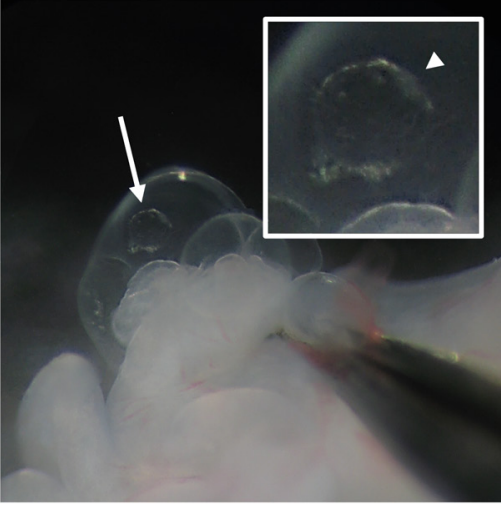

C

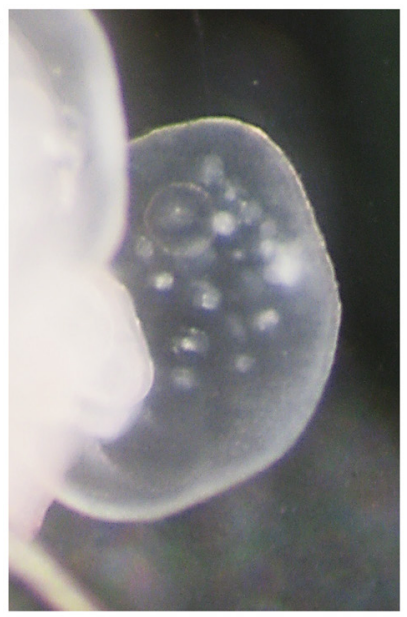

$D$ i)
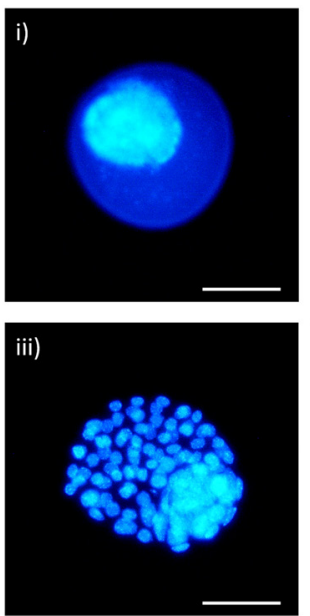

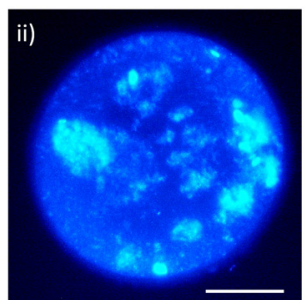

iv)

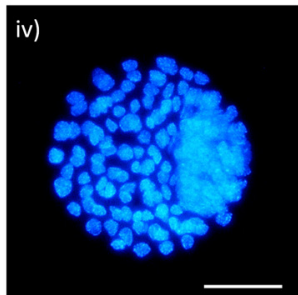

Figure 5 Oviductal dilations result in oocyte and embryo entrapment. (A) Oviductal dilation of a Yap/Taz ${ }^{\mathrm{f} / \mathrm{f}}$; Amhr ${ }^{\text {cre/+ }}$ containing oocytes (arrow). Inset shows a higher magnification. Stain = hematoxylin phloxine saffron (HPS). (B) Photomicrograph showing a blastocyst (arrow) in an oviductal dilation of a Yap/Taz ${ }^{\mathrm{f} / \mathrm{f}} ;$ Amhr $2^{\text {cre/+ }}$ female $7.5 \mathrm{dpc}$. Inset shows a higher magnification. Arrowhead indicate the ICM. (C) Photomicrograph of an oviductal dilation containing debris including degenerated oocytes and embryos. (D) Fluorescent images of DAPI-stained unfertilized oocyte (i), degenerated embryo (ii) and $6.5 \mathrm{dpc}$ unhatched blastocysts (iii, iv) retrieved by oviductal flushing. Scale bars are $200 \mu \mathrm{m}$ (A), $25 \mu \mathrm{m}$ (A - inset) and $50 \mu \mathrm{m}$ (D).
Gonzalez \& Behringer 2009). Hippo has been shown to be involved in both the TGF- $\beta / S M A D$ signaling pathway (Varelas et al. 2008, Varelas et al. 2010, Lv et al. 2019) and in miRNA processing (Chaulk et al. 2014, Mori et al. 2014) in other cellular contexts. We thus investigated the possible involvement of these two processes in the development of the $\mathrm{Yap} / \mathrm{Taz} z^{\mathrm{fff}} ; A m h r 2^{\text {cre/+ }}$ oviduct phenotype. By immunohistochemistry, SMAD2 and p-SMAD3 expression levels and localization were found to be similar in the oviducts of 10-month-old mutant and control animals. Signal was mainly cytoplasmic for SMAD2 and exclusively cytoplasmic for p-SMAD3 (Suppl Fig. 2A and B). Dicer1 mRNA levels were unchanged in the isthmus of 3-week and 2-month-old $\mathrm{Yap} / \mathrm{Taz}^{\mathrm{ff}} ; \mathrm{Amhr} 2^{\mathrm{cre} /+}$ mice (Fig. 6A), as were levels of the key vascular-associated smooth muscle cell miRNA miR143 (Cordes et al. 2009), which was previously shown to be downregulated in both the Tgfbr flox/bgal $^{\text {f Amhr2 }} 2^{\text {cre/ }}$ (Li et al. 2011) and Dicer ${ }^{\text {f/-; }}$ Amhr $2^{\text {cre/+ }}$ models (Nagaraja et al. 2008) (Fig. 6B). Likewise, immunohistochemistry analyses showed that DICER1 and DDX17 expression levels and localization were unchanged in isthmi of 10-month-old mutant animals (Suppl Fig. 2C and D).

Irregular myosalpinx was also reported in transgenic mice with conditionally activated Notch 1 in Amhr2- expressing tissues (Ferguson et al. 2016). Additionally, Yap/Taz deletion in neural crest precursors results in failure to produce vascular smooth muscle cells (Manderfield et al. 2015), accompanied by the downregulation of the Notch target genes c-Myc, Hrt3 and Jagged 1 . We therefore evaluated their mRNA levels in isthmus lysates (together with $\mathrm{Cd} d 2$ and Notch2, two genes regulated by Hippo (Rayon et al. 2014, Yimlamai et al. 2014)), but found their expression in Yap/Taz $z^{\text {fff; }}$ Amhr ${ }^{\text {cre/t+ }}$ females to be similar to controls (Suppl Fig. 3).

We also evaluated the expression of genes involved in myogenic determination of cells of the mesenchymal lineage, in addition to markers of smooth muscle cell differentiation. The mRNA levels of myogenic precursor genes Myf5, Myod 1 and Myog were unchanged in isthmi from Yap/Taz ${ }^{\mathrm{ff}} ; \mathrm{Amhr}^{\mathrm{cre} / \mathrm{+}}$ mice relative to controls (Fig. 6C). Markers of smooth muscle cell differentiation such as Acta2, Cald1, Cnn1, Des, Myh11, Smtn and Tag/n were likewise unaffected (Fig. 6D). Finally, mRNA levels of the Hippo target genes Cyr61, Ctgf, Nov, Birc5 and -7 were evaluated in 3-week-old animals. Contrary to expectation, Nov, Birc5 and -7 expression was significantly elevated in isthmus lysates of $\mathrm{Yap} / \mathrm{Taz}^{\mathrm{f} / \mathrm{f}}$; Amhrr ${ }^{\text {cre/t }}$ females (Fig. 6E). 

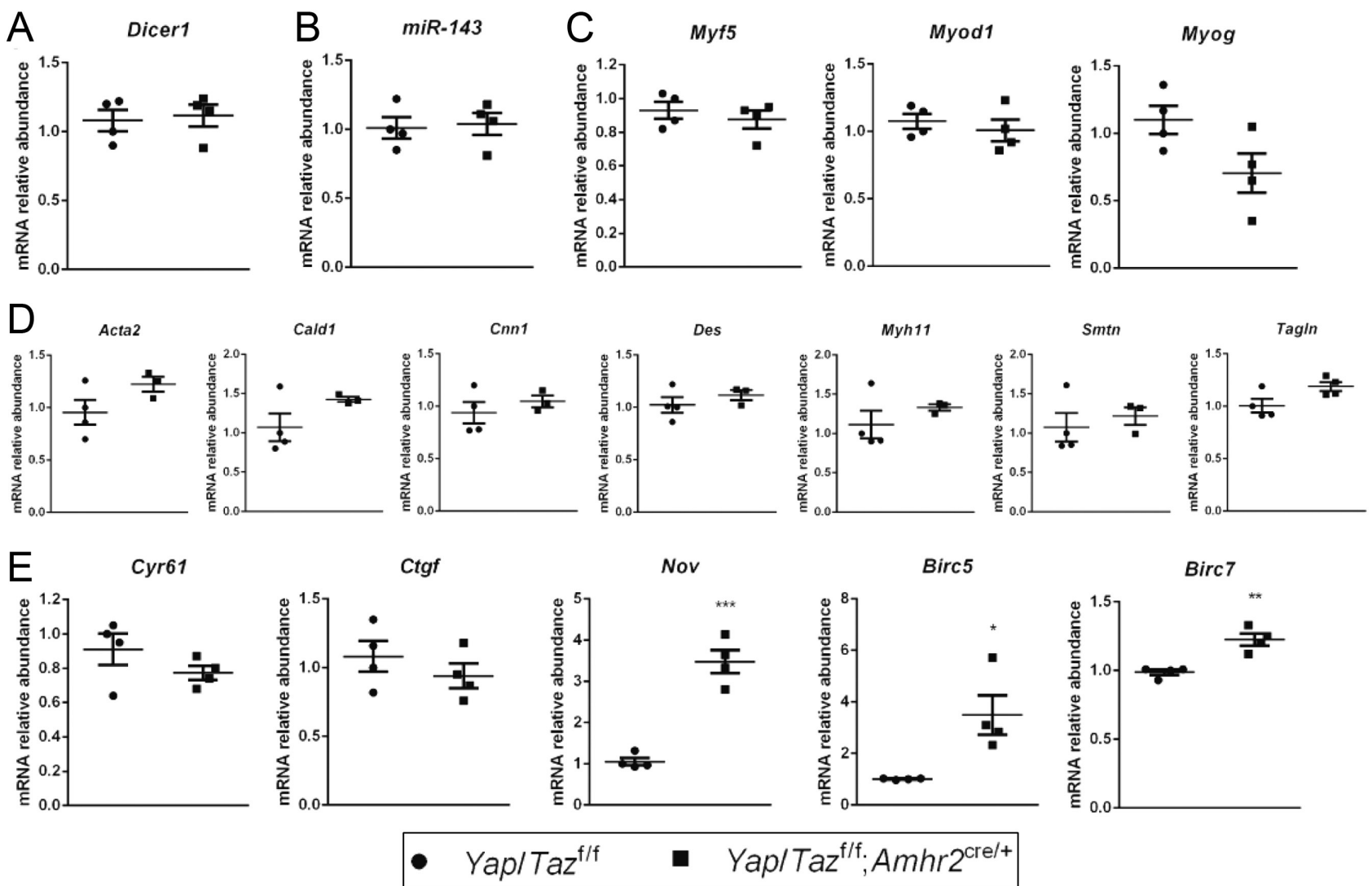

$\mathrm{Yap} / \mathrm{Taz}^{\mathrm{f} / \mathrm{f}}$ - $\mathrm{Yap} / \mathrm{Taz}^{\mathrm{f} / \mathrm{f}} ; \mathrm{Amhr}^{\mathrm{cre} / \mathrm{+}}$

Figure 6 mRNA expression in Yap/Taz ${ }^{\mathrm{fff}}$; Amhr $2^{\text {cre/ }+}$ isthmi is only moderately affected. RT-qPCR analyses of isthmus lysates of 3-week-old Yap/Taz ${ }^{\mathrm{fff}}$ and Yap/Taz $z^{\mathrm{fff}}$; Amhr2 ${ }^{\mathrm{cre} / \mathrm{+}}$ females for Dicer1 (A), miR-143 (B), myogenic precursors Myf5, Myod1 and Myog (C), markers of smooth muscle cell differentiation Acta2, Cald1, Cnn1, Des, Myh11, Smtn and TagIn (D) and Hippo target genes Cyr61, Ctgf, Nov, Birc5 and -7 (E). Data are means \pm S.E.M. analyzed by Student's $t$-tests. ${ }^{*} P<0.05 .{ }^{* *} P<0.01$. ${ }^{* * *} P<0.001 . n=4$.

\section{Discussion}

\section{YAP and TAZ are necessary for the proper postnatal development of the myosalpinx}

Although a recent study showed that conditional deletion of Lats 1 and -2 in the Müllerian mesenchyme resulted in cell fate decision defects apparently due to increased expression of YAP and TAZ and their target genes (St-Jean et al. 2019), the roles of YAP and TAZ in the physiological context of female reproductive tract development and function remained unclear. Here, we show that conditional inactivation of Yap and Taz in the oviduct results in disorderly development of the myosalpinx of the isthmus after the age of 3 weeks, suggesting their involvement in some aspect of oviduct smooth muscle cell biology. Roles for the Hippo pathway in smooth muscle cells have been previously reported. For instance, the inactivation of Hippo either by pharmacological inhibition or by siRNA has been shown to decrease proliferation in cultured airway (Fu et al. 2017, Liu et al. 2018) and intestinal (Dai et al. 2018) smooth muscle cells. In a model of cultured rat carotid vascular smooth muscle cells, injury resulted in increased TEAD transcriptional activity, higher YAP and CTGF levels and enhanced proliferation (Chen \& Liu 2018). Likewise, the YAP/TAZ transcriptional target genes Cyr61, Ctgf and Nov have been shown to be involved in vascular smooth muscle cell proliferation (Lee et al. 2007, Shimoyama et al. 2010, Hwang et al. 2018). However, we failed to detect any differences in smooth muscle cell proliferation in the oviducts of Yap/Taz ${ }^{\mathrm{f} / \mathrm{f}} ;$ Amhr $2^{\mathrm{cre} /+}$ mice, and our analyses of YAP/TAZ target gene expression did not show decreases in mRNA levels of Cyr61, Ctgf or Nov. Furthermore, expression of smooth muscle cell markers seemed to indicate that smooth muscle cell differentiation and overall numbers of cells were unchanged, and we could not find evidence of increased apoptosis within the myosalpinx. The cellular mechanism underlying the formation of the discontinuities in the myosalpinx therefore remains unclear. One possibility is that YAP/TAZ are involved in regulating smooth muscle cell migration or cell-cell adhesion, as has been shown in other cell types (Fu et al. 2017, Nardone et al. 2017, Chen \& Liu 2018), and that defects in these processes cause gaps to form in the myosalpinx, and/or result in an oviduct wall of inadequate tensile strength. Further experiments will be required to test these hypotheses. 
Loss of YAP and TAZ resulted in the development of oviductal dilations which prevented adequate embryo transport

Lower levels of Yap and Taz mRNA and protein levels were first observed in the oviducts of 3-week-old $\mathrm{Yap} / \mathrm{Taz}^{\mathrm{f} / \mathrm{f}} ; A \mathrm{mhr} 2^{\mathrm{cre} /+}$ mice, and led to the later formation of myosalpinx continuity defects by two months of age. Though difficult to prove beyond doubt, the oviductal dilations appeared to originate from these defects, which were presumed to be structural weak points in the oviduct wall. Intraluminal pressure and the movement of oviductal fluid provide a likely explanation for the progressive increase in the volume of these dilations with age. The fact that the myosalpinx represents a proportionally greater structural component of the wall of the isthmus in comparison with the ampulla may explain why the dilations were always located at the isthmus.

In mice, embryos enter the uterine lumen around the late morula stage at $3.5 \mathrm{dpc}$ (Wang \& Dey 2006). The presence of blastocysts in the oviducts of the Yap/Taz f/f; Amhr $2^{\text {cre/t }}$ model at $6.5 \mathrm{dpc}$ was thus highly abnormal. The mouse uterus is refractory to implantation from 5.5 dpc onwards (Wang \& Dey 2006). Considering the tight window of opportunity for implantation in mice, even a slightly delayed uterine entry would presumably result in a failure to implant. This idea combined with the near absence of implantation sites observed in 5-monthold Yap/Taz ${ }^{\mathrm{f} / \mathrm{f}} ; A m h r 2^{\text {cre/+ }}$ at $6.5 \mathrm{dpc}$, clearly shows that the development of oviductal dilations is responsible for the subfertility observed in this model. This is also concordant with the fertility assay, which showed that fertility is not impaired in the first few litters, but rather decreases dramatically with age, in parallel with the formation and growth of the oviduct dilations.

Transport of embryos through the oviductal lumen is driven by the beating of the cilia of the epithelial cells and by rhythmic contractions of the myosalpinx (mainly in the ampulla and in the isthmus, respectively). Using a calcium channel antagonist to paralyze the myosalpinx, Dixon et al. (2009) demonstrated that oviduct cilia beating alone is not sufficient to propel oocytes through the oviductal lumen. We therefore postulate that disruption of the integrity of the oviduct wall in the Yap/Taz ${ }^{\mathrm{ff}} ; A m h r 2^{\text {cre/ }+}$ model causes subfertility by entrapping embryos in cystic dilations, but also by preventing effective contractions of the isthmus myosalpinx, thereby resulting in inadequate transport of embryos toward the uterus. Retrograde sperm transport did not seem to be fully hindered, given the presence of fertilized embryos within the dilations.

\section{Poor recombination efficiency in the Yap/Taz ${ }^{\mathrm{f} / \mathrm{f}}$; Amhr2 ${ }^{\text {cre/+ }}$ model}

The Amhr2 $2^{\text {cre }}$ model has been shown to direct efficient recombination in Müllerian mesenchyme cells as early as e14.5 (Jamin et al. 2002), and ovarian granulosa cells

Reproduction (2020) $160307-318$ from the secondary follicle stage onward (Jorgez et al. 2004). Why Cre-mediated inactivation of Yap and Taz was inefficient in the ovary and uterus and only occurred to an appreciable extent in the oviduct of the Yap/Taz ${ }^{\mathrm{ff}}$; Amhr2 $2^{\text {cre/+ }}$ model remains unknown. Importantly, our study does not preclude roles for Yap and Taz during Müllerian duct and uterine development or in ovarian physiology. However, more efficient Cre models and/or Yap/Taz floxed alleles will likely have to be developed in order to address these questions by conditional gene targeting. Likewise, even within the oviduct, Yap/Taz inactivation was not complete in the Yap/Taz ${ }^{\mathrm{f} / \mathrm{f}} ; \mathrm{Amhr}{ }^{\mathrm{cre} /+}$ model, and perhaps earlier or more marked phenotypic changes would have arisen had this process been more efficient.

\section{The molecular mechanisms underlying Yap/Taz ${ }^{\mathrm{f} / f}$; Amhr2 ${ }^{\text {cre/t }}$ oviduct defects are distinct from models with similar phenotypic changes}

The oviductal dilation and myosalpinx development defects that occur in Yap/Taz $;$ Amhr2 ${ }^{\text {cre/ } /+}$ females strikingly resemble those of previously reported mouse models of conditional deletion of Tgfbr 1 (Li et al. 2011), Smad1/5/4 (Rodriguez et al. 2016) and Dicer1 (Hong et al. 2008, Nagaraja et al. 2008, Gonzalez \& Behringer 2009). This seemed particularly pertinent given that Hippo had previously been shown to interact with the TGF- $\beta / S M A D$ pathway and to affect miRNA processing in certain cell types. For instance, in mouse granulosa cells, Yap knockdown resulted in the alteration of TGF $\beta 1-$ induced phosphorylation of SMAD2 and SMAD3, along with downregulation of Tgfbr1 (Lv et al. 2019). YAP and TAZ have also been shown to be involved in the control of the subcellular localization of phosphorylated receptor-regulated SMADs (Varelas et al. 2008, 2010). Chaulk et al. (2014) showed that nuclear YAP/TAZ are required to maintain high Dicer levels and for pre-miRNA processing in human mammary gland cells. Furthermore, high levels of YAP can suppress miRNA synthesis by limiting the association of the Microprocessor with its cofactor DDX17 (Mori et al. 2014). These previous studies therefore directed our mechanistic investigations of the Yap/Taz $z^{\mathrm{fff}} ; A m h r 2^{\mathrm{cre} /+}$ phenotype toward TGF- $\beta$ / SMAD signaling and miRNA synthesis. However, we were unable detect the dysregulation of either of these processes in the Yap/Taz"; $;$ Amhr $2^{\text {cre/+ }}$ model.

Ferguson et al. (2016) reported that oviducts of transgenic mice with conditionally activated Notch 1 in Amhr2-expressing tissues consisted entirely of small cysts, and that the myosalpinx was irregular. Considering that Yap/Taz deletion in neural crest precursors results in the downregulation of Notch target genes and failure to produce smooth muscle cells (Manderfield et al. 2015), we investigated possible misregulation of the Notch pathway in the development of the Yap/Taz ${ }^{\mathrm{f} / \mathrm{f}}$; Amhr $2^{\text {cre/t }}$ oviductal phenotype, but failed to find any evidence of this. The molecular mechanisms underlying

https://rep.bioscientifica.com 
the development of oviduct defects in the Yap/Taz $z^{\mathrm{ff}}$; $A m h r 2^{\text {cre/t }}$ model therefore remain to be determined, but appear not to involve alterations in TGF-B/SMAD or Notch signaling, miRNA biogenesis or loss of expression of smooth muscle cell markers or well-characterized YAP/TAZ transcriptional target genes.

In conclusion, this is the first report demonstrating a role of the Hippo pathway in oviductal smooth muscle cells. YAP and TAZ were found to be necessary for the maintenance of oviduct integrity, adequate embryo transport and fertility in aging female mice. Future studies would be required to better define the mechanism by which YAP and TAZ regulate oviductal smooth muscle cell physiology and how they might be involved in the development of other tissues derived from the Müllerian ducts.

\section{Supplementary materials}

This is linked to the online version of the paper at https://doi. org/10.1530/REP-20-0202.

\section{Declaration of interest}

The authors declare that there is no conflict of interest that could be perceived as prejudicing the impartiality of the research reported.

\section{Funding}

This work was supported by a project grant of the Canadian Institutes of Health Research (CIHR) to DB (MOP-142445). PG was supported by a doctoral training research award from the Fonds de Recherche du Québec - Santé (FRQS). The University of Virginia Center for Research in Reproduction Ligand Assay and Analysis Core is supported by the Eunice Kennedy Shriver NICHD/NIH (NCTRI) Grant P50-HD28934.

\section{Author contribution statement}

P G performed murine work, acquisition, analysis and interpretation of data and drafting of the manuscript. M T performed murine work. M P performed interpretation of the data. D B designed the study, interpreted the data, drafted and revised the manuscript.

\section{Acknowledgments}

The authors thank Claude Paquet, Jacinthe Cardin and Meggie Girard (all from Université de Montréal) for technical support. The authors thank Eric Olson (UT Southwestern Medical Center) and Richard R. Behringer (M.D. Anderson Cancer Center) for generously providing $\mathrm{Yap}^{\mathrm{f} / \mathrm{f}}, \mathrm{Taz}^{\mathrm{f} / \mathrm{f}}$ and $\mathrm{Amhr} 2^{\mathrm{cre}}$ mice.

\section{References}

Chaulk SG, Lattanzi VJ, Hiemer SE, Fahlman RP \& Varelas X 2014 The Hippo pathway effectors TAZ/YAP regulate dicer expression and microRNA biogenesis through Let-7. Journal of Biological Chemistry 289 1886-1891. (https://doi.org/10.1074/jbc.C113.529362)
Chen B \& Liu G 2018 WWC3 inhibits intimal proliferation following vascular injury via the Hippo signaling pathway. Molecular Medicine Reports 17 5175-5183. (https://doi.org/10.3892/mmr.2018.8484)

Chen H, Song Y, Yang S, Fu J, Feng X \& Huang W 2017 YAP mediates human decidualization of the uterine endometrial stromal cells. Placenta 53 30-35. (https://doi.org/10.1016/j.placenta.2017.03.013)

Cordes KR, Sheehy NT, White MP, Berry EC, Morton SU, Muth AN, Lee T-H, Miano JM, Ivey KN \& Srivastava D 2009 miR-145 and miR-143 regulate smooth muscle cell fate and plasticity. Nature 460 705-710. (https://doi. org/10.1038/nature08195)

Dixon RE, Hwang SJ, Hennig GW, Ramsey KH, Schripsema JH, Sanders KM \& Ward SM 2009 Chlamydia infection causes loss of pacemaker cells and inhibits oocyte transport in the mouse Oviduct1. Biology of Reproduction 80 665-673. (https://doi.org/10.1095/biolreprod.108.073833)

Dai LN, Yan JK, Xiao YT, Wen J, Zhang T, Zhou KJ, Wang Y \& Cai W 2018 Butyrate stimulates the growth of human intestinal smooth muscle cells by activation of yes-associated protein. Journal of Cellular Physiology 233 3119-3128. (https://doi.org/10.1002/jcp.26149)

Deb K, Reese J \& Paria BC 2006 Methodologies to study implantation in mice. Methods in Molecular Medicine 121 9-34. (https://doi. org/10.1385/1-59259-983-4:007)

Dixon RE, Hwang SJ, Hennig GW, Ramsey KH, Schripsema JH, Sanders KM \& Ward SM 2009 Chlamydia infection causes loss of pacemaker cells and inhibits oocyte transport in the mouse Oviduct1. Biology of Reproduction 80 665-673. (https://doi.org/10.1095/biolreprod.108.073833)

Ferguson L, Kaftanovskaya EM, Manresa C, Barbara AM, Poppiti RJ, Tan Y \& Agoulnik Al 2016 Constitutive Notch signaling causes abnormal development of the oviducts, abnormal angiogenesis, and cyst formation in mouse female reproductive tract. Biology of Reproduction 9467. (https://doi.org/10.1095/biolreprod.115.134569)

Fu J, Zheng M, Zhang X, Zhang Y, Chen Y, Li H, Wang X \& Zhang J 2017 Fibulin-5 promotes airway smooth muscle cell proliferation and migration via modulating Hippo-YAP/TAZ pathway. Biochemical and Biophysical Research Communications 493 985-991. (https://doi. org/10.1016/j.bbrc.2017.09.105)

Gonzalez G \& Behringer RR 2009 Dicer is required for female reproductive tract development and fertility in the mouse. Molecular Reproduction and Development 76 678-688. (https://doi.org/10.1002/mrd.21010)

Hansen CG, Moroishi T \& Guan KL 2015 YAP and TAZ: a nexus for Hippo signaling and beyond. Trends in Cell Biology 25 499-513. (https://doi. org/10.1016/j.tcb.2015.05.002)

Hong X, Luense LJ, McGinnis LK, Nothnick WB \& Christenson LK 2008 Dicer1 is essential for female fertility and normal development of the female reproductive system. Endocrinology 149 6207-6212. (https://doi. org/10.1210/en.2008-0294)

Hossain Z, Ali SM, Ko HL, Xu J, Ng CP, Guo K, Qi Z, Ponniah S, Hong W \& Hunziker W 2007 Glomerulocystic kidney disease in mice with a targeted inactivation of Wwtr1. PNAS 104 1631-1636. (https://doi. org/10.1073/pnas.0605266104)

Hwang AR, Nam JO \& Kang YJ 2018 Fluvastatin inhibits advanced glycation end products-induced proliferation, migration, and extracellular matrix accumulation in vascular smooth muscle cells by targeting connective tissue growth factor. Korean Journal of Physiology and Pharmacology 22 193-201. (https://doi.org/10.4196/kjpp.2018.22.2.193)

Jamin SP, Arango NA, Mishina Y, Hanks MC \& Behringer RR 2002 Requirement of Bmpr1a for Müllerian duct regression during male sexual development. Nature Genetics 32 408-410. (https://doi.org/10.1038/ ng1003)

Jorgez CJ, Klysik M, Jamin SP, Behringer RR \& Matzuk MM 2004 Granulosa cell-specific inactivation of follistatin causes female fertility defects. Molecular Endocrinology 18 953-967. (https://doi.org/10.1210/ me.2003-0301)

Kobayashi A, Shawlot W, Kania A \& Behringer RR 2004 Requirement of Lim1 for female reproductive tract development. Development 131 539-549. (https://doi.org/10.1242/dev.00951)

Lau LF \& Lam SCT 1999 The CCN family of angiogenic regulators: the integrin connection. Experimental Cell Research 248 44-57. (https://doi. org/10.1006/excr.1999.4456)

Lee HY, Chung JW, Youn SW, Kim JY, Park KW, Koo BK, Oh BH, Park YB, Chaqour B, Walsh K et al. 2007 Forkhead transcription factor FOXO3a is a negative regulator of angiogenic immediate early gene CYR61, leading to inhibition of vascular smooth muscle cell proliferation and 
neointimal hyperplasia. Circulation Research 100 372-380. (https://doi. org/10.1161/01.RES.0000257945.97958.77)

Li Q, Agno JE, Edson MA, Nagaraja AK, Nagashima T \& Matzuk MM 2011 Transforming growth factor beta receptor type 1 is essential for female reproductive tract integrity and function. PLoS Genetics 7 e1002320. (https://doi.org/10.1371/journal.pgen.1002320)

Liu CY, Zha ZY, Zhou X, Zhang H, Huang W, Zhao D, Li T, Chan SW, Lim CJ, Hong W et al. 2010 The hippo tumor pathway promotes TAZ degradation by phosphorylating a phosphodegron and recruiting the SCF $\{$ beta\}-TrCP E3 ligase. Journal of Biological Chemistry 285 37159-37169. (https://doi.org/10.1074/jbc.M110.152942)

Liu L, Zhai C, Pan Y, Zhu Y, Shi W, Wang J, Yan X, Su X, Song Y, Gao L et al. 2018 Sphingosine-1-phosphate induces airway smooth muscle cell proliferation, migration, and contraction by modulating Hippo signaling effector YAP. American Journal of Physiology: Lung Cellular and Molecular Physiology 315 L609-L621. (https://doi.org/10.1152/ ajplung.00554.2017)

Lv X, He C, Huang C, Wang H, Hua G, Wang Z, Zhou J, Chen X, Ma B, Timm BK et al. 2019 Timely expression and activation of YAP1 in granulosa cells is essential for ovarian follicle development. FASEB Journal 33 10049-10064. (https://doi.org/10.1096/fj.201900179RR)

Manderfield LJ, Aghajanian H, Engleka KA, Lim LY, Liu F, Jain R, Li L, Olson EN \& Epstein JA 2015 Hippo signaling is required for Notchdependent smooth muscle differentiation of neural crest. Development 142 2962-2971. (https://doi.org/10.1242/dev.125807)

Meng Z, Moroishi T \& Guan KL 2016 Mechanisms of Hippo pathway regulation. Genes and Development 30 1-17. (https://doi.org/10.1101/ gad.274027.115)

Miyamoto N, Yoshida M, Kuratani S, Matsuo I \& Aizawa S 1997 Defects of urogenital development in mice lacking Emx2. Development 124 1653-1664.

Mori M, Triboulet R, Mohseni M, Schlegelmilch K, Shrestha K, Camargo FD \& Gregory RI 2014 Hippo signaling regulates microprocessor and links cell density-dependent miRNA biogenesis to cancer. Cell 156 893-906. (https://doi.org/10.1016/j.cell.2013.12.043)

Morin-Kensicki EM, Boone BN, Howell M, Stonebraker JR, Teed J, Alb JG, Magnuson TR, O'Neal W \& Milgram SL 2006 Defects in yolk sac vasculogenesis, chorioallantoic fusion, and embryonic axis elongation in mice with targeted disruption of Yap65. Molecular and Cellular Biology 26 77-87. (https://doi.org/10.1128/MCB.26.1.77-87.2006)

Nagaraja AK, Andreu-Vieyra C, Franco HL, Ma L, Chen R, Han DY, Zhu H, Agno JE, Gunaratne PH, DeMayo FJ et al. 2008 Deletion of Dicer in somatic cells of the female reproductive tract causes sterility. Molecular Endocrinology 22 2336-2352. (https://doi.org/10.1210/me.2008-0142)

Nardone G, Oliver-De La Cruz J, Vrbsky J, Martini C, Pribyl J, Skládal P, Pešl M, Caluori G, Pagliari S, Martino F et al. 2017 YAP regulates cell mechanics by controlling focal adhesion assembly. Nature Communications 815321 15321. (https://doi.org/10.1038/ncomms15321)

Patel SH, Camargo FD \& Yimlamai D 2017 Hippo signaling in the liver regulates organ size, cell fate, and carcinogenesis. Gastroenterology 152 533-545. (https://doi.org/10.1053/j.gastro.2016.10.047)

Pfaffl MW 2001 A new mathematical model for relative quantification in real-time RT-PCR. Nucleic Acids Research 29 e45. (https://doi. org/10.1093/nar/29.9.e45)

Piccolo S, Dupont S \& Cordenonsi M 2014 The biology of YAP/TAZ: hippo signaling and beyond. Physiological Reviews 94 1287-1312. (https://doi. org/10.1152/physrev.00005.2014)

Plouffe SW, Lin KC, Moore JL, 3rd, Tan FE, Ma S, Ye Z, Qiu Y, Ren B \& Guan KL 2018 The Hippo pathway effector proteins YAP and TAZ have both distinct and overlapping functions in the cell. Journal of Biological Chemistry 293 11230-11240. (https://doi.org/10.1074/jbc.RA118.002715)

Rayon T, Menchero S, Nieto A, Xenopoulos P, Crespo M, Cockburn K, Cañon S, Sasaki H, Hadjantonakis AK, de la Pompa JL et al. 2014 Notch and hippo converge on $\mathrm{Cdx} 2$ to specify the trophectoderm lineage in the mouse blastocyst. Developmental Cell 30 410-422. (https://doi. org/10.1016/j.devcel.2014.06.019)

Rodriguez A, Tripurani SK, Burton JC, Clementi C, Larina I \& Pangas SA 2016 SMAD signaling is required for structural integrity of the female reproductive tract and uterine function During early pregnancy in mice. Biology of Reproduction 95 44. (https://doi.org/10.1095/biolreprod.116.139477)

Roly ZY, Backhouse B, Cutting A, Tan TY, Sinclair AH, Ayers KL, Major AT \& Smith CA 2018 The cell biology and molecular genetics of Mullerian duct development. Wiley Interdisciplinary Reviews: Developmental Biology 7 e310. (https://doi.org/10.1002/wdev.310)

Shi P, Feng J \& Chen C 2015 Hippo pathway in mammary gland development and breast cancer. Acta Biochimica et Biophysica Sinica 47 53-59. (https://doi.org/10.1093/abbs/gmu114)

Shimoyama T, Hiraoka S, Takemoto M, Koshizaka M, Tokuyama H, Tokuyama T, Watanabe A, Fujimoto M, Kawamura $H$, Sato $S$ et al. 2010 CCN3 inhibits neointimal hyperplasia through modulation of smooth muscle cell growth and migration. Arteriosclerosis, Thrombosis, and Vascular Biology 30 675-682. (https://doi.org/10.1161/ ATVBAHA.110.203356)

St-Jean G, Tsoi M, Abedini A, Levasseur A, Rico C, Morin M, Djordjevic B, Miinalainen I, Kaarteenaho R, Paquet M et al. 2019 Lats1 and Lats2 are required for the maintenance of multipotency in the Müllerian duct mesenchyme. Development 146 dev180430. (https://doi.org/10.1242/ dev.180430)

Strakova Z, Reed J \& Ihnatovych I 2010 Human transcriptional coactivator with PDZ-binding motif (TAZ) is downregulated during decidualization. Biology of Reproduction 82 1112-1118. (https://doi.org/10.1095/ biolreprod.109.081844)

Torres M, Gomez-Pardo E, Dressler GR \& Gruss P 1995 Pax-2 controls multiple steps of urogenital development. Development 121 4057-4065.

Vainio S, Heikkila M, Kispert A, Chin N \& McMahon AP 1999 Female development in mammals is regulated by Wnt-4 signalling. Nature 397 405-409. (https://doi.org/10.1038/17068)

Varelas X, Sakuma R, Samavarchi-Tehrani P, Peerani R, Rao BM, Dembowy J, Yaffe MB, Zandstra PW \& Wrana JL 2008 TAZ controls Smad nucleocytoplasmic shuttling and regulates human embryonic stem-cell self-renewal. Nature Cell Biology 10 837-848. (https://doi. org/10.1038/ncb1748)

Varelas X, Samavarchi-Tehrani P, Narimatsu M, Weiss A, Cockburn K, Larsen BG, Rossant J \& Wrana JL 2010 The crumbs complex couples cell density sensing to Hippo-dependent control of the TGF-beta-SMAD pathway. Developmental Cell 19 831-844. (https://doi.org/10.1016/j. devcel.2010.11.012)

Wang H \& Dey SK 2006 Roadmap to embryo implantation: clues from mouse models. Nature Reviews: Genetics 7 185-199. (https://doi. org/10.1038/nrg1808)

Wong JS, Meliambro K, Ray J \& Campbell KN 2016 Hippo signaling in the kidney: the good and the bad. American Journal of Physiology: Renal Physiology 311 F241-F248. (https://doi.org/10.1152/ajprenal.00500.2015)

Xin M, Kim Y, Sutherland LB, Qi X, McAnally J, Schwartz RJ, Richardson JA, Bassel-Duby R \& Olson EN 2011 Regulation of insulin-like growth factor signaling by Yap governs cardiomyocyte proliferation and embryonic heart size. Science Signaling 4 ra70. (https://doi.org/10.1126/scisignal.2002278)

Xin M, Kim Y, Sutherland LB, Murakami M, Qi X, McAnally J, Porrello ER, Mahmoud Al, Tan W, Shelton JM et al. 2013 Hippo pathway effector Yap promotes cardiac regeneration. PNAS 110 13839-13844. (https://doi. org/10.1073/pnas.1313192110)

Yimlamai D, Christodoulou C, Galli GG, Yanger K, Pepe-Mooney B, Gurung B, Shrestha K, Cahan P, Stanger BZ \& Camargo FD 2014 Hippo pathway activity influences liver cell fate. Cell 157 1324-1338. (https:// doi.org/10.1016/j.cell.2014.03.060)

Zhao B, Wei X, Li W, Udan RS, Yang Q, Kim J, Xie J, Ikenoue T, Yu J, Li L et al. 2007 Inactivation of YAP oncoprotein by the Hippo pathway is involved in cell contact inhibition and tissue growth control. Genes and Development 21 2747-2761. (https://doi.org/10.1101/gad.1602907)

Zhao B, Li L, Tumaneng K, Wang CY \& Guan KL 2010 A coordinated phosphorylation by Lats and CK1 regulates YAP stability through SCF(beta-TRCP). Genes and Development 24 72-85. (https://doi. org/10.1101/gad.1843810)

Zhou Q, Li L, Zhao B \& Guan KL 2015 The hippo pathway in heart development, regeneration, and diseases. Circulation Research 116 1431-1447. (https://doi.org/10.1161/CIRCRESAHA.116.303311)

Received 9 April 2020

First decision 14 May 2020

Revised manuscript received 27 May 2020

Accepted 1 June 2020 